\title{
Heat capacity and phase equilibria of hollandite polymorph of $\mathrm{KAISi}_{3} \mathrm{O}_{8}$
}

Received: 16 August 2005/ Accepted: 17 January 2006/Published online: 18 February 2006 (C) Springer-Verlag 2006

\begin{abstract}
The low-temperature heat capacity $\left(C_{p}\right)$ of $\mathrm{KAlSi}_{3} \mathrm{O}_{8}$ with a hollandite structure was measured over the range of 5-303 $\mathrm{K}$ with a physical properties measurement system. The standard entropy of KAl$\mathrm{Si}_{3} \mathrm{O}_{8}$ hollandite is $166.2 \pm 0.2 \mathrm{~J} \mathrm{~mol}^{-1} \mathrm{~K}^{-1}$, including an $18.7 \mathrm{~J} \mathrm{~mol}^{-1} \mathrm{~K}^{-1}$ contribution from the configurational entropy due to disorder of $\mathrm{Al}$ and $\mathrm{Si}$ in the octahedral sites. The entropy of $\mathrm{K}_{2} \mathrm{Si}_{4} \mathrm{O}_{9}$ with a wadeite structure (Si-wadeite) was also estimated to facilitate calculation of phase equilibria in the system $\mathrm{K}_{2} \mathrm{O}$ $\mathrm{Al}_{2} \mathrm{O}_{3}-\mathrm{SiO}_{2}$. The calculated phase equilibria obtained using Perple_x are in general agreement with experimental studies. Calculated phase relations in the system $\mathrm{K}_{2} \mathrm{O}-\mathrm{Al}_{2} \mathrm{O}_{3}-\mathrm{SiO}_{2}$ confirm a substantial stability field for kyanite-stishovite/coesite-Si-wadeite intervening between $\mathrm{KAlSi}_{3} \mathrm{O}_{8}$ hollandite and sanidine. The upper stability of kyanite is bounded by the reaction kyanite $\left(\mathrm{Al}_{2} \mathrm{SiO}_{5}\right)=$ corundum $\left(\mathrm{Al}_{2} \mathrm{O}_{3}\right)+$ stishovite $\left(\mathrm{SiO}_{2}\right)$, which is located at $13-14 \mathrm{GPa}$ for $1,100-1,400 \mathrm{~K}$. The entropy and enthalpy of formation for K-cymrite $\left(\mathrm{KAlSi}_{3} \mathrm{O}_{8} \cdot \mathrm{H}_{2} \mathrm{O}\right)$ were modified to better fit global bestfit compilations of thermodynamic data and experimental studies. Thermodynamic calculations were undertaken on the reaction of $\mathrm{K}$-cymrite to $\mathrm{KAlSi}_{3} \mathrm{O}_{8}$ hollandite $+\mathrm{H}_{2} \mathrm{O}$, which is located at $8.3-10.0 \mathrm{GPa}$ for the temperature range $800-1,600 \mathrm{~K}$, well inside the stability field of stishovite. The reaction of muscovite to $\mathrm{KAlSi}_{3} \mathrm{O}_{8}$ hollandite + corundum $+\mathrm{H}_{2} \mathrm{O}$ is placed at
\end{abstract}

W. Yong $(\bowtie) \cdot$ E. J. Essene

Department of Geological Sciences, University of Michigan, Ann Arbor, MI 48109-1005, USA

E-mail: wenjuny@umich.edu

Tel.: + 1-734-6475533

Fax: + 1-734-7634690

E. Dachs

Fachbereich Materialwissenschaften, Universität Salzburg, Hellbrunnerstr. 34, 5020, Salzburg, Austria

A. C. Withers

Department of Geology and Geophysics,

University of Minnesota, Minneapolis, MN 55455, USA
$10.0-10.6 \mathrm{GPa}$ for the temperature range $900-1,500 \mathrm{~K}$, in reasonable agreement with some but not all experiments on this reaction.

Keywords Hollandite $\cdot \mathrm{KAlSi}_{3} \mathrm{O}_{8} \cdot \mathrm{Si}$-wadeite $\cdot$ $\mathrm{K}$-cymrite $\cdot$ Heat capacity $\cdot$ High-pressure phase equilibria $\cdot$ Thermodynamic calculation

\section{Introduction}

Ringwood et al. (1967) first discovered that potassium feldspar transforms into a hollandite structure when pressure exceeds $12 \mathrm{GPa}$. The $\mathrm{K}$ atoms in $\mathrm{KAlSi}_{3} \mathrm{O}_{8}$ hollandite are accommodated in tunnels formed by double chains of edge-sharing $(\mathrm{Si}, \mathrm{Al}) \mathrm{O}_{6}$ octahedra (Ringwood et al. 1967; Yamada et al. 1984; Zhang et al. 1993). Kinomura et al. (1975) found an intermediatepressure assemblage of kyanite $\left(\mathrm{Al}_{2} \mathrm{SiO}_{5}\right)$, coesite $\left(\mathrm{SiO}_{2}\right)$, and $\mathrm{K}_{2} \mathrm{Si}_{4} \mathrm{O}_{9}$ with a wadeite structure (Si-wadeite) separating the stability field of sanidine at low pressure and $\mathrm{KAlSi}_{3} \mathrm{O}_{8}$ hollandite at high pressure. This was verified by additional experiments (Urakawa et al. 1994; Yagi et al. 1994). The lower stability of $\mathrm{KAlSi}_{3} \mathrm{O}_{8}$ hollandite was located at pressures of 8-10 GPa for temperatures of $1,000-1,500 \mathrm{~K}$. With one-fourth of the $\mathrm{Si}$ atoms in octahedral sites, the structure of Si-wadeite $\left(\mathrm{K}_{2} \mathrm{Si}_{4} \mathrm{O}_{9}\right)$ can be considered as three-membered rings of $\mathrm{SiO}_{4}$ tetrahedra connected by octahedrally coordinated $\mathrm{Si}$ atoms (Kinomura et al. 1977; Swanson and Prewitt 1983). Liu (1978) reported $\mathrm{KAlSi}_{3} \mathrm{O}_{8}$ hollandite plus a high-pressure form of $\mathrm{KAlO}_{2}$ forming from kalsilite $\left(\mathrm{KAlSiO}_{4}\right)$ in the pressure range of 17-30 GPa. Faust and Knittle (1994) documented the breakdown of a natural muscovite to $\mathrm{KAlSi}_{3} \mathrm{O}_{8}$ hollandite + corundum $+\mathrm{H}_{2} \mathrm{O}$ at pressures between 10.9 and $12.0 \mathrm{GPa}$ at around $1,073 \mathrm{~K}$. The phase $\mathrm{KAlSi}_{3} \mathrm{O}_{8}$ hollandite has also been reported in hydrated average upper continental crust, MORB, andesite, and pelite compositions when pressure is greater than $8 \mathrm{GPa}$ (Irifune et al. 1994; Schmidt 1996; Domanik and Holloway 1996, 2000; Ono 1998; Wang 
and Takahashi 1999). Electron microprobe (EMP) analyses of run product hollandite by Domanik and Holloway (2000) show $14-30 \%$ deficiencies in the $\mathrm{K}$ site that are not matched by excess $\mathrm{Si}$. They inferred that phengite decomposed to $\mathrm{KAlSi}_{3} \mathrm{O}_{8}$ hollandite between 9 and $10 \mathrm{GPa}$ at $900^{\circ} \mathrm{C}$. Domanik and Holloway (2000) noted that their hollandite was damaged by the electron beam but did not correct for elemental migration. Their low K site occupancies probably represent an analytical artifact rather than a vacancy substitution. Examination of their assemblages suggests progress of the reaction muscovite + coesite/stishovite $=\mathrm{KAlSi}_{3} \mathrm{O}_{8}$ hollandite + kyanite + fluid, as well as more complex reactions that involve magnesite, garnet and $\mathrm{OH}$-topaz. Konzett and Fei (2000) reported $\mathrm{KAlSi}_{3} \mathrm{O}_{8}$ hollandite as one of the breakdown products at $20-23 \mathrm{GPa}$ and $1,773-$ $1,973 \mathrm{~K}$ in peralkaline and subalkaline rock compositions. Quench experiments by Tutti et al. (2001) showed that $\mathrm{KAlSi}_{3} \mathrm{O}_{8}$ hollandite is still stable at pressure as high as $95 \mathrm{GPa}$, consistent with previous suggestions that $\mathrm{KAlSi}_{3} \mathrm{O}_{8}$ hollandite is an important host for potassium in the lower mantle (Ringwood 1975; Prewitt and Downs 1998). Occurrences of natural $\mathrm{KAlSi}_{3} \mathrm{O}_{8}$ hollandite and $\mathrm{NaAlSi}_{3} \mathrm{O}_{8}$ hollandite $\left(\mathrm{NaAlSi}_{3} \mathrm{O}_{8}\right.$ with hollandite structure) have been reported in shocked meteorites (Akaogi 2000; Gillet et al. 2000; Langenhorst and Poirier 2000; Tomioka et al. 2000; Kimura et al. 2003). Sueda et al. (2004) demonstrated that $\mathrm{KAlSi}_{3} \mathrm{O}_{8}$ hollandite transforms to a new high-pressure phase $\left(\mathrm{KAlSi}_{3} \mathrm{O}_{8}\right.$ hollandite II) at $\sim 22 \mathrm{GPa}$ at room temperature using in situ $\mathrm{X}$-ray diffraction. They related this transition to the abrupt enrichments of $\mathrm{Ca}$ and $\mathrm{Na}$ components in $\mathrm{KAlSi}_{3} \mathrm{O}_{8}$ hollandite coexisting with a potassic basalt melt at $\sim 22.5 \mathrm{GPa}$ observed by Wang and Takahashi (1999). In situ X-ray diffraction study by Nishiyama et al. (2005) confirmed that this transition happens at pressures of 20-23 GPa and temperatures of 300-1,000 K. Collectively, the experimental studies suggest that $\mathrm{KAlSi}_{3} \mathrm{O}_{8}$ hollandite has an important role in transporting potassium during subduction of oceanic crust into the deep mantle.

The thermodynamic properties of several phases are in need of further study in order to accurately determine the phase equilibria in the system $\mathrm{K}_{2} \mathrm{O}-\mathrm{Al}_{2} \mathrm{O}_{3}-\mathrm{SiO}_{2}$, although some measurements have been made. The enthalpy of Si-wadeite and $\mathrm{KAlSi}_{3} \mathrm{O}_{8}$ hollandite was determined by Geisinger et al. (1987) and Akaogi et al. (2004) using high-temperature solution calorimetry. The high-temperature heat capacity of Si-wadeite was measured by Fasshauer et al. (1998). They generated an internally consistent thermodynamic data set for several phases but did not include $\mathrm{KAlSi}_{3} \mathrm{O}_{8}$ hollandite in their evaluation. Akaogi et al. (2004) measured the hightemperature heat capacity data of $\mathrm{KAlSi}_{3} \mathrm{O}_{8}$ hollandite and reevaluated the phase relations in the system $\mathrm{K}_{2} \mathrm{O}-$ $\mathrm{Al}_{2} \mathrm{O}_{3}-\mathrm{SiO}_{2}$ by combining thermodynamic with experimental data. However, an approach totally independent of the experiments has not been applied to this system because the lack of low-temperature heat capacity data, and hence lack of entropy and Gibbs free energy, of the high-pressure phases. In this study, the low-temperature heat capacity of $\mathrm{KAlSi}_{3} \mathrm{O}_{8}$ hollandite was measured using a physical properties measurement system (PPMS, produced by Quantum Design $(\AA)$, and the entropy of $\mathrm{KAlSi}_{3} \mathrm{O}_{8}$ hollandite was calculated from the measured heat capacity data. The entropy of Si-wadeite was estimated from Holland (1989), and phase relations in the system $\mathrm{K}_{2} \mathrm{O}-\mathrm{Al}_{2} \mathrm{O}_{3}-\mathrm{SiO}_{2}$ were calculated based on the new thermodynamic data. Several reactions involving $\mathrm{KAlSi}_{3} \mathrm{O}_{8}$ hollandite were also investigated in the system $\mathrm{K}_{2} \mathrm{O}-\mathrm{Al}_{2} \mathrm{O}_{3}-\mathrm{SiO}_{2}-\mathrm{H}_{2} \mathrm{O}$.

\section{Experimental procedures}

Sample synthesis and characterization

The $\mathrm{KAlSi}_{3} \mathrm{O}_{8}$ hollandite was synthesized using a 1,000ton Walker-type multi-anvil device at the University of Minnesota. Tungsten carbide anvils with $8 \mathrm{~mm}$ truncations, cast $\mathrm{MgO}-\mathrm{Cr}_{2} \mathrm{O}_{3}$ octahedra with $14 \mathrm{~mm}$ edge lengths and pyrophyllite gaskets were used for this study. $\mathrm{KAlSi}_{3} \mathrm{O}_{8}$ glass from Craig Manning at UCLA was used as the starting material. It was powdered and loaded into a cylindrical Re capsule, which also acts as the furnace. After being held at $14 \mathrm{GPa}$ and $1,673 \mathrm{~K}$ for $24 \mathrm{~h}$, the starting material was quenched at $14 \mathrm{GPa}$ and slowly recovered to ambient pressure. Temperature was controlled by a $\mathrm{W}_{3} \mathrm{Re}_{97} / \mathrm{W}_{25} \mathrm{Re}_{75}$ thermocouple oriented vertically with respect to the heater.

The run product was confirmed to be $\mathrm{KAlSi}_{3} \mathrm{O}_{8}$ hollandite by X-ray diffraction and EMP analysis. The tetragonal lattice parameters of the synthesized KAl$\mathrm{Si}_{3} \mathrm{O}_{8}$ hollandite were determined using the Scintag Crystallography program as $a=9.313(3) \AA$ and $c=2.723(3) \mathrm{A}$, which are in good agreement with the values, $a=9.315(4) \AA$ and $c=2.723(4) \AA$, by Zhang et al. (1993) and deviate only slightly from the data, $a=9.3244(4) \AA$ and $c=2.7227(3) \AA$, of Yamada et al. (1984). The EMP analyses were performed using Cameca SX-100, and the avarage values for 25 runs of $\mathrm{KAlSi}_{3} \mathrm{O}_{8}$ hollandite are shown in Table 1 . The column conditions were: accelerating voltage $15 \mathrm{kV}$, beam current $4 \mathrm{nA}$, peak and background counting times each $10 \mathrm{~s}$, and beam scan area $5 \times 5 \mu^{2}$. The low current was used because preliminary analyses showed the sensitivity of hollandite to an electron beam. The standards used for $\mathrm{Na}, \mathrm{Mg}, \mathrm{Fe}, \mathrm{Al}, \mathrm{Si}$, and $\mathrm{K}$ are Tiburon albite, synthetic $\mathrm{MgTiO}_{3}$, synthetic $\mathrm{FeSiO}_{3}$, K-feldspar from St. Gotthard, respectively. The small amounts of $\mathrm{Na}, \mathrm{Mg}$, and $\mathrm{Fe}$ are around the detection limits, and their effects on the heat capacity measurement are negligible. Compared to previous EMP studies on synthetic $\mathrm{KAlSi}_{3} \mathrm{O}_{8}$ hollandite that indicated an apparent deficiency on the K site (Irifune et al. 1994; Schmidt 1996; Domanik and Holloway 1996, 2000; Ono 1998; Wang and Takahashi 1999), the EMP analyses in this study shows no evidence for a vacancy on that site. Less accurate TEM analyses 
Table 1 Average composition of $\mathrm{KAlSi}_{3} \mathrm{O}_{8}$ glass and $\mathrm{KAlSi}_{3} \mathrm{O}_{8}$ hollandite determined by EMP

\begin{tabular}{lccccccc}
\hline Phase & $\mathrm{SiO}_{2}(\mathrm{wt} \%)$ & $\mathrm{Al}_{2} \mathrm{O}_{3}$ & $\mathrm{~K}_{2} \mathrm{O}$ & $\mathrm{MgO}$ & $\mathrm{Na}_{2} \mathrm{O}$ & $\mathrm{FeO}$ & $\mathrm{Sum}$ \\
\hline $\mathrm{KAlSi}_{3} \mathrm{O}_{8}$ (glass) & 64.57 & 17.63 & 16.92 & 0.01 & 0.01 & 0.02 \\
$\mathrm{SD}$ (wt \%) & 0.38 & 0.15 & 0.48 & 0.01 & 0.02 & 0.03 \\
Cations per 8 O & 3.018 & 0.971 & 1.009 & 0.001 & 0.001 & 0.001 \\
$\mathrm{KAlSi}_{3} \mathrm{O}_{8}$ (hollandite) & 64.30 & 18.34 & 17.36 & 0.04 & 0.04 & 0.19 \\
$\mathrm{SD}$ (wt \%) & 0.64 & 0.44 & 0.32 & 0.02 & 0.04 & 0.09 \\
Cations per 8 O & 2.983 & 1.003 & 1.027 & 0.003 & 0.004 & 0.007 \\
\hline
\end{tabular}

of natural $\mathrm{KAlSi}_{3} \mathrm{O}_{8}$ hollandite from shock metamorphosed meteorites also showed an apparent vacancy on the $\mathrm{K}$ site (Langenhorst and Poirier 2000). It will be assumed that the $\mathrm{KAlSi}_{3} \mathrm{O}_{8}$ hollandite in this study is pure and stoichiometric.

\section{Heat capacity measurement}

The low-temperature heat capacity at constant pressure $\left(C_{p}\right)$ of $\mathrm{KAlSi}_{3} \mathrm{O}_{8}$ hollandite was measured at $1 \mathrm{~atm}$ using the heat capacity option of the PPMS at Salzburg University in Austria. Based on heat-pulse calorimetry (HPC), the PPMS is the first commercially available apparatus that can measure the low-temperature heat capacity of samples with milligram mass. Lashley et al. (2003) and Dachs and Bertoldi (2005) provided a detailed description of the PPMS, its use in heat capacity measurements, and an evaluation of measurement errors. The technique is summarized below.

The central part of the PPMS calorimeter is the calorimeter puck, made up of the puck frame and the sample platform that holds the sample. The sample holder is a $4 \times 4 \mathrm{~mm}^{2}$ wide sapphire platform that has a thermometer and a heater attached to the lower side. Thin Pt wires attached to the sample platform provide the electrical connection and structural support between the platform and the puck frame. The puck is covered with a cap and resides at the base of a sample chamber, the inner part of the PPMS probe that is directly immersed in a liquid helium bath.

In HPC as employed in the PPMS calorimeter, a known amount of heat is applied to a sample at selected temperatures, and the resultant temperature change is recorded. Two separate measurements, known as "addenda run" and "sample run", are carried out for the quantitative determination of heat capacity. In an addenda run, the heat capacity of the empty sample platform plus some grease applied to it is determined based on Fourier's law of heat conduction and the law of conservation of energy, as the following equation:

$P(t)=C_{p}^{\mathrm{pl}} \frac{\mathrm{d} T_{\mathrm{pl}}(t)}{\mathrm{d} t}+K_{\mathrm{w}}\left(T_{\mathrm{pl}}(t)-T_{b}\right)$,

where "pl" stands for platform, $\mathrm{d} T_{\mathrm{pl}}(t) / \mathrm{d} t$ is the thermal response of the platform to which a square pulse of heat $P(t)$ is applied, $K_{\mathrm{w}}$ is the thermal conductance of the wires (in units $\mathrm{W} \mathrm{K}^{-1}$ ) and $T_{b}$ is the temperature of the puck frame. A non-linear least-squares fit to the analytical solutions of equation (1) (Dachs and Bertoldi 2005: their equations $6 \mathrm{a}, 6 \mathrm{~b}$ ) yields the heat capacity of the empty sample platform, $C_{p}^{\mathrm{pl}}$, at the temperature $T_{\mathrm{pl}}$. This procedure is then repeated at the desired temperature with the sample mounted on the sample platform during the sample run. The equations that describe the heat balance conditions in this case are:

$$
\left\{\begin{array}{c}
P(t)=C_{p}^{\mathrm{pl}} \frac{\mathrm{d} T_{\mathrm{pl}}(t)}{\mathrm{d} t}+K_{\mathrm{W}}\left(T_{\mathrm{pl}}(t)-T_{b}\right)+K_{\mathrm{g}}\left(T_{\mathrm{pl}}(t)-T_{\mathrm{s}}(t)\right) \\
0=C_{p}^{\mathrm{s}} \frac{\mathrm{d} T_{\mathrm{s}}(t)}{\mathrm{d} t}+K_{\mathrm{g}}\left(T_{\mathrm{s}}(t)-T_{\mathrm{pl}}(t)\right)
\end{array},\right.
$$

where $K_{\mathrm{g}}$ is the thermal conductance due to the grease between the sample and the sample platform, $T_{\mathrm{s}}$ and $C_{p}^{\mathrm{s}}$ are the temperature and the heat capacity of the sample, respectively. Because $T_{\mathrm{pl}}$ can be directly mearured by PPMS, elimination of $T_{\mathrm{s}}$ in Eq. 2 will generate:

$$
\begin{gathered}
\frac{\mathrm{d}^{2} T_{\mathrm{pl}}}{\mathrm{d} t^{2}}+\frac{\mathrm{d} T_{\mathrm{pl}}}{\mathrm{d} t}\left[\frac{\left(C_{p}^{\mathrm{s}} K_{\mathrm{w}} / K_{\mathrm{g}}+C_{p}^{\mathrm{s}}+C_{p}^{\mathrm{pl}}\right) K_{\mathrm{g}}}{C_{p}^{\mathrm{s}} C_{p}^{\mathrm{pl}}}\right]+\frac{K_{\mathrm{w}} K_{\mathrm{g}}}{C_{p}^{\mathrm{s}} C_{p}^{\mathrm{pl}}} T_{\mathrm{pl}} \\
=\frac{K_{\mathrm{g}}}{C_{p}^{\mathrm{s}} C_{p}^{\mathrm{pl}}}\left[\frac{C_{p}^{\mathrm{s}}}{K_{\mathrm{g}}} \frac{\mathrm{d} P(t)}{\mathrm{d} t}+P(t)+K_{\mathrm{w}} T_{b}\right] .
\end{gathered}
$$

As $C_{p}^{\mathrm{pl}}$ is already known from the addenda run, the remaining four unknowns: $K_{\mathrm{g}}, K_{\mathrm{w}}, T_{b}$, and $C_{p}^{\mathrm{s}}$, are calculated by applying the same non-linear least square fitting routine to the analytical solution of equation (3) (Dachs and Bertoldi 2005,: their Eqs. 10a, 10b) based on the temperature-time response curve measured during the sample run (40-200 data pairs for each measurement at a specific temperature). The standard deviation (SD), $\sigma_{C_{p}}$, of each measurement can also be obtained from this fitting procedure. The heat capacity contribution of the container is subtracted from the total heat capacity to give the net heat capacity of the unknown samples. Dachs and Bertoldi (2005) showed that heat capacity measurements on sealed powders by PPMS were systematically lower than low-temperature adiabatic calorimetry (LTAC) data by $1-2 \%$ in the temperature range between 100 and $300 \mathrm{~K}$. At 5-20 K, where the absolute values of heat capacity are small, the measured data by PPMS may be up to $50 \%$ larger than those measured by LTAC. The entropies at $298.15 \mathrm{~K}$ derived from PPMS heat capacity measurements are at maximum $1-2 \%$ lower than those calculated from LTAC experiments (Dachs and Bertoldi 2005). 


\section{Results}

Heat capacity and entropy of $\mathrm{KAlSi}_{3} \mathrm{O}_{8}$ hollandite

The measured molar heat capacity $\left(C_{p}\right)$ of $\mathrm{KAlSi}_{3} \mathrm{O}_{8}$ hollandite versus temperature is listed in Table 2 and shown in Fig. 1. To obtain the entropy of $\mathrm{KAlSi}_{3} \mathrm{O}_{8}$ hollandite, a general polynomial with $C_{p}=k_{0}+$ $k_{1} T^{-0.5}+k_{2} T^{-2}+k_{3} T^{-3}+k_{4} T+k_{5} T^{2}+k_{6} T^{3}$ was chosen to fit the $C_{p}$ data in Table 2 using the Experimental Data Analyst Package of Mathematica ${ }^{\circledR}$.The data were split into three temperature regions and each region was fitted individually with some overlap of data. The equation $C_{p}=k_{0}+k_{1} T^{-0.5}+k_{2} T^{2}+$ $k_{3} T^{-3}$ was used for fitting the high temperature portion of the data, the complete polynomial given above for the intermediate temperature portion and $C_{p}=k_{4} T+k_{6} T^{3}$ is for fitting at low temperature. The $C_{p}$ data below $5 \mathrm{~K}$ were estimated by a linear extrapolation to $0 \mathrm{~K}$ from the lowest measured $C_{p}$ point in the form of $C_{p}=k_{6} T^{3}$. The resulting $C_{p}$ coefficients and temperatures at interval boundaries are given in Table 3, where the final entropy value varies only insignificantly (only in the second digit) upon choosing a different splitting temperature of the $C_{p}$ data (Table 3, Fit 1 compared to Fit 2). The uncertainty in the entropy at standard temperature and pressure was estimated by a Monte Carlo technique. A detailed description of error estimation is provided in Dachs and Bertoldi (2005). The entropy of $\mathrm{KAlSi}_{3} \mathrm{O}_{8}$ hollandite at $298.15 \mathrm{~K}$ calculated by integration of these fitted functions is $147.5 \pm 0.2 \mathrm{~J} \mathrm{~mol}^{-1} \mathrm{~K}^{-1}$ (error is $1 \mathrm{SD}$ ). The crystal structure refinement of $\mathrm{KAlSi}_{3} \mathrm{O}_{8}$ hollandite shows that $\mathrm{Al}$ and $\mathrm{Si}$ atoms are fully disordered over the octahedral sites (Yamada et al. 1984; Zhang et al. 1993), thus requiring addition of the configurational entropy, $S_{0}^{\circ}$ to the entropy term. The configurational entropy is calculated as $S_{0}^{\circ}=-4 R(0.25 \ln 0.25+0.75 \ln 0.75)=$ $18.7 \mathrm{~J} \mathrm{~mol}^{-1} \mathrm{~K}^{-1}$. Including this contribution, the entropy

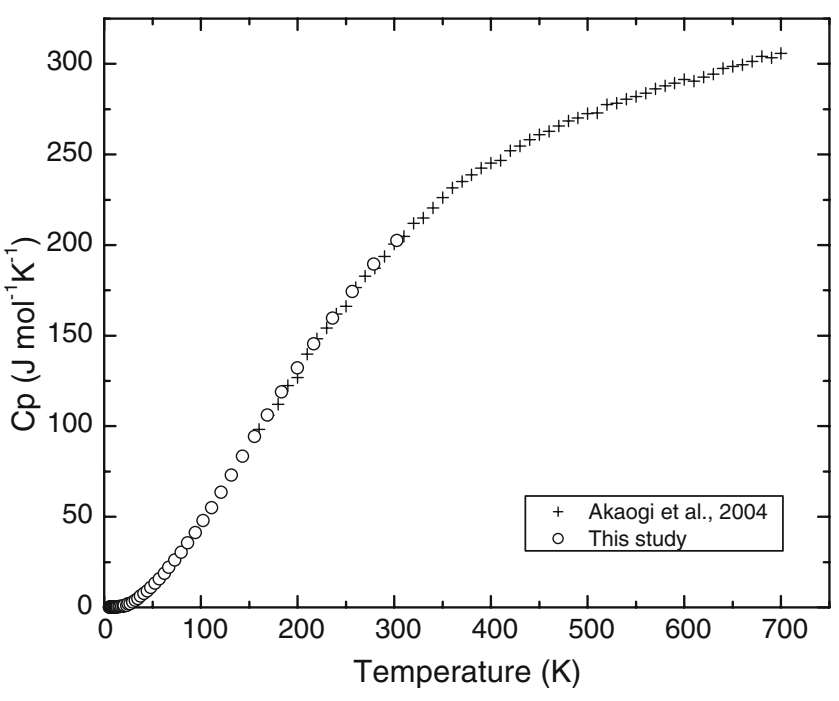

Fig. 1 Comparison of the low- $T C_{p}$ of $\mathrm{KAlSi}_{3} \mathrm{O}_{8}$ hollandite measured using the PPMS calorimeter in this study with high- $T$ $C_{p}$ data from Akaogi et al. (2004)

obtained for $\mathrm{KAlSi}_{3} \mathrm{O}_{8}$ hollandite at standard temperature and pressure (STP) is $166.2 \pm 0.2 \mathrm{~J} \mathrm{~mol}^{-1} \mathrm{~K}^{-1}$. That value is in striking disagreement with the value of $65.3 \mathrm{~J} \mathrm{~mol}^{-1} \mathrm{~K}^{-1}$ that was estimated by Domanik and Holloway (2000). Their estimate was derived by summation techniques based on a complex dehydration reaction involving phengite in the system KMASH and is likely to have large errors that were not evaluated.

The high-temperature $C_{p}$ data of $\mathrm{KAlSi}_{3} \mathrm{O}_{8}$ hollandite were measured by Akaogi et al. (2004) using differential scanning calorimetry. Their data were used for calculation of the enthalpy and entropy above ambient temperature (Table 4). The smooth fit of our $C_{p}$ data with that of Akaogi et al. (2004) provides strong support for the STP entropy obtained in this study but not for the estimate of Domanik and Holloway (2000).
Table 2 Heat capacity of $\mathrm{KAlSi}_{3} \mathrm{O}_{8}$ hollandite

\begin{tabular}{rlllrl}
\hline$T(\mathrm{~K})$ & $C_{p}\left(\mathrm{~J} \mathrm{~mol}^{-1} \mathrm{~K}^{-1}\right)$ & $T(\mathrm{~K})$ & $C_{p}\left(\mathrm{~J} \mathrm{~mol}^{-1} \mathrm{~K}^{-1}\right)$ & $T(\mathrm{~K})$ & $C_{p}\left(\mathrm{~J} \mathrm{~mol}^{-1} \mathrm{~K}^{-1}\right)$ \\
\hline 5.06 & $0.0177(6)$ & 20.87 & $1.059(20)$ & 86.45 & $35.52(40)$ \\
5.52 & $0.0231(6)$ & 22.68 & $1.371(25)$ & 93.95 & $41.36(43)$ \\
6.00 & $0.031(1)$ & 24.65 & $1.792(37)$ & 102.17 & $47.91(44)$ \\
6.52 & $0.038(1)$ & 26.80 & $2.307(44)$ & 111.41 & $55.13(46)$ \\
7.08 & $0.049(1)$ & 29.14 & $2.986(58)$ & 120.78 & $63.77(46)$ \\
7.69 & $0.059(1)$ & 31.68 & $3.807(73)$ & 131.31 & $73.05(48)$ \\
8.36 & $0.078(1)$ & 34.45 & $4.810(89)$ & 142.77 & $83.25(51)$ \\
9.08 & $0.096(2)$ & 37.46 & $6.02(11)$ & 155.22 & $94.20(50)$ \\
9.86 & $0.123(2)$ & 40.74 & $7.48(14)$ & 168.72 & $106.16(51)$ \\
10.72 & $0.158(3)$ & 44.29 & $9.03(17)$ & 183.49 & $118.93(51)$ \\
11.65 & $0.195(4)$ & 48.15 & $11.00(21)$ & 199.47 & $132.06(53)$ \\
12.67 & $0.247(5)$ & 52.35 & $13.25(23)$ & 216.98 & $145.75(54)$ \\
13.76 & $0.310(6)$ & 56.92 & $15.87(26)$ & 235.83 & $159.92(59)$ \\
14.96 & $0.395(7)$ & 61.88 & $18.81(29)$ & 256.48 & $174.27(55)$ \\
16.25 & $0.500(9)$ & 67.28 & $22.16(34)$ & 278.71 & $189.62(67)$ \\
17.67 & $0.638(11)$ & 73.14 & $26.05(35)$ & 303.10 & $202.66(70)$ \\
19.20 & $0.818(15)$ & 79.52 & $30.30(39)$ & & \\
\end{tabular}

The $C_{p}$ data were measured with PPMS on $17.9 \mathrm{mg}$ sample material 
Table 3 Coefficients of the $C_{p}$ polynomial $C_{p}=k_{0}+k_{1} T^{-0.5}+$ $k_{2} T^{-2}+k_{3} T^{-3}+k_{4} T+k_{5} T^{2}+k_{6} T^{3}$ derived by fitting the PPMS $C_{p}$ data of $\mathrm{KAlSi}_{3} \mathrm{O}_{8}$ hollandite given in Table 2

\begin{tabular}{lcc}
\hline Formula weight & \multicolumn{2}{l}{$403.129 \mathrm{~g} / \mathrm{mol} 17.91 \mathrm{mg}$} \\
\cline { 2 - 3 } Sample weight & Fit 1 & Fit 2 \\
\hline$k_{6}$ & $1.3828 \mathrm{E}-04$ & $1.3828 \mathrm{E}-04$ \\
$T_{1}$ & 5.18 & 4.63 \\
$k_{0}$ & $3.8615 \mathrm{E}+00$ & $-5.7192 \mathrm{E}+00$ \\
$k_{1}$ & $-9.3952 \mathrm{E}+00$ & $1.2055 \mathrm{E}+01$ \\
$k_{2}$ & $4.0668 \mathrm{E}+01$ & $-3.7451 \mathrm{E}+01$ \\
$k_{3}$ & $-7.4326 \mathrm{E}+01$ & $5.7584 \mathrm{E}+01$ \\
$k_{4}$ & $-1.5636 \mathrm{E}-01$ & $3.3438 \mathrm{E}-01$ \\
$k_{5}$ & $3.8436 \mathrm{E}-03$ & $-1.3217 \mathrm{E}-02$ \\
$k_{6}$ & $8.4027 \mathrm{E}-05$ & $3.2949 \mathrm{E}-04$ \\
$T_{2}$ & 33.55 & 24.83 \\
$k_{2}$ & $-5.1104 \mathrm{E}+02$ & $1.0604 \mathrm{E}+02$ \\
$k_{4}$ & $-7.3461 \mathrm{E}-02$ & $-1.3806 \mathrm{E}-01$ \\
$k_{5}$ & $7.2435 \mathrm{E}-03$ & $9.0294 \mathrm{E}-03$ \\
$k_{6}$ & $-1.8727 \mathrm{E}-05$ & $-3.0671 \mathrm{E}-05$ \\
$T_{3}$ & 122.36 & 91.31 \\
$k_{0}$ & $6.4504 \mathrm{E}+02$ & $6.3640 \mathrm{E}+02$ \\
$k_{1}$ & $-8.2990 \mathrm{E}+03$ & $-8.1129 \mathrm{E}+03$ \\
$k_{2}$ & $3.6393 \mathrm{E}+06$ & $3.3807 \mathrm{E}+06$ \\
$k_{3}$ & $-1.3325 \mathrm{E}+08$ & $-1.1687 \mathrm{E}+08$ \\
$T_{\text {ref }}$ & 298.15 & 298.15 \\
$C_{p}$ at 298 & $200.3(7)$ & $200.2(7)$ \\
$S^{\circ}{ }_{298}$ & $147.45(19)$ & $147.49(18)$ \\
\hline$A t$ & &
\end{tabular}

At the bottom of the table, heat capacity at $298.15 \mathrm{~K}$ and standard entropy $S_{0}$ are additionally given (numbers in parenthesis is 1SD and apply to the last digits). Fit 1 and Fit 2 only differ by the choice of temperatures $T_{1}, T_{2}$ and $T_{3}$ at which the $C_{p}$ data have been split into subsets

Entropy of Si-wadeite and phase equilibria in $\mathrm{K}_{2} \mathrm{O}-\mathrm{Al}_{2} \mathrm{O}_{3}-\mathrm{SiO}_{2}$ system

High-pressure experimental studies on the phase transitions in $\mathrm{KAlSi}_{3} \mathrm{O}_{8}$ were carried out by Yagi et al. (1994) and Urakawa et al. (1994) on the following reactions:

2sanidine $=$ Si-wadeite + kyanite + coesite.

Si-wadeite + kyanite + coesite $=2 \mathrm{KAlSi}_{3} \mathrm{O}_{8}$ hollandite.

Si-wadeite + kyanite + stishovite

$$
=2 \mathrm{KAlSi}_{3} \mathrm{O}_{8} \text { hollandite. }
$$

The experimental results are shown in Fig. 2. The experiments by Yagi et al. (1994) were revised by Akaogi et al. (2004) because the original pressure calibration was mainly on the coesite-stishovite transition by Yagi and Akimoto (1976), which is 0.3-0.4 GPa higher than the most recent work by Zhang et al. (1996). The results after recalibration are comparable to the in situ X-ray experiments of Urakawa et al. (1994), which were based on a $\mathrm{NaCl}$ pressure scale.

Thermodynamic calculations were undertaken with the computer program Perple_x (Connolly and Kerrick 1987; Connolly 1990) using a modified Holland and Powell (1998) data base, and including the new data from this research for $\mathrm{KAlSi}_{3} \mathrm{O}_{8}$ hollandite and $\mathrm{Si}$ wadeite. Table 4 shows the sources of phase properties involved in this study. For the solid phases, the temperature dependence of the molar volume, $\mathrm{V}^{\circ}(\mathrm{T})$, is given by

$$
V^{\circ}(T)=V_{298}^{\circ}\left(1+\int_{298}^{T} \alpha \mathrm{d} T\right),
$$

where $\alpha$ and $V_{298}^{\circ}$ are the thermal expansion and molar volume at standard state, respectively. The pressure dependence of the molar volume was calculated using the Murnaghan equation of state:

$V(T, P)=V^{\circ}(T)\left(1+\frac{K_{0 T}^{\prime}}{K_{0 T}} P\right)^{-\frac{1}{K_{0 T}^{\prime}}}$,

where $K_{0 T}$ and $K_{0 T}^{\prime}$ are the isothermal bulk modulus and its pressure derivative, respectively. The compensated-Redlich-Kwong (CORK) equation from Holland and Powell $(1991,1998)$ was chosen for the PVTbehavior of $\mathrm{H}_{2} \mathrm{O}$.

Unfortunately, the entropy of Si-wadeite has not been determined calorimetrically. Fasshauer et al. (1998) estimated a value of $232 \pm 10 \mathrm{~J} \mathrm{~mol}^{-1} \mathrm{~K}^{-1}$ for $S^{\circ}{ }_{298}$ of Si-wadeite, about $33 \mathrm{~J} \mathrm{~mol}^{-1} \mathrm{~K}^{-1}$ larger than that calculated by Geisinger et al. (1987) from spectroscopic data. This is partly supported by the systematically higher $C_{p}$ observed by differential scanning calorimetry (DSC) at $T<500 \mathrm{~K}$ than that derived from vibrational spectroscopy (Fasshauer et al., 1998). Thermodynamic calculations using Perple_x also favor a larger value for $S^{\circ}{ }_{298}$ of Si-wadeite. The calculated phase relations using $S^{\circ}{ }_{298 \text { (wad) }}=232 \pm 10 \mathrm{~J} \mathrm{~mol}^{-1} \mathrm{~K}^{-1}$ are shown in Fig. 2 (dashed lines). Unfortunately, large discrepancies remain between the calculated phase boundaries and the experimental data of Yagi et al. (1994) and Urakawa et al. (1994). An even larger value for $S^{\circ}{ }_{298}$ of Si-wadeite is necessitated to fit the experimental data with thermodynamic calculation.

The $S^{\circ}{ }_{298}$ of Si-wadeite was therefore estimated from Holland (1989) as follows:

$$
\begin{aligned}
S_{298_{(\mathrm{wad})}}^{\circ} & =\left(3 \mathrm{SiO}_{\mathrm{Si}_{2}}^{[4]}+S_{\mathrm{SiO}_{2}}^{[6]}+S_{\mathrm{K}_{2} \mathrm{O}(a)}\right)+k\left[V_{298(\mathrm{wad})}^{\circ}\right. \\
& \left.\times-\left(3 V_{\mathrm{SiO}_{2}}^{[4]}+V_{\mathrm{SiO}_{2}}^{[6]}+V_{\mathrm{K}_{2} \mathrm{O}(a)}\right)\right] \\
& =k V_{298(\mathrm{wad})}^{\circ}+3(S-k V){ }_{\mathrm{SiO}_{2}}^{[4]}+(S-k V){ }_{\mathrm{SiO}_{2}}^{[6]} \\
& +(S-k V)_{\mathrm{K}_{2} \mathrm{O}(a)} \\
& =108.44+3 \times 17.45+10.49+79.55 \cong 251 \\
& \pm 4 \mathrm{~J} \mathrm{~mol}^{-1} \mathrm{~K}^{-1}
\end{aligned}
$$

where $k=1.0 \mathrm{~J} \mathrm{~K}^{-1} \mathrm{~cm}^{-3}$, which corresponds to solidsolid reactions involving no change in coordination state that have $\mathrm{d} P / \mathrm{d} T=10$ bar K $^{-1}$. The values of $(S-k V)_{\mathrm{SiO}_{2}}^{[4]}$ and $(S-k V)_{\mathrm{K}_{2} \mathrm{O}_{(a)}}$ can be found in Holland (1989), which are calculated from the 


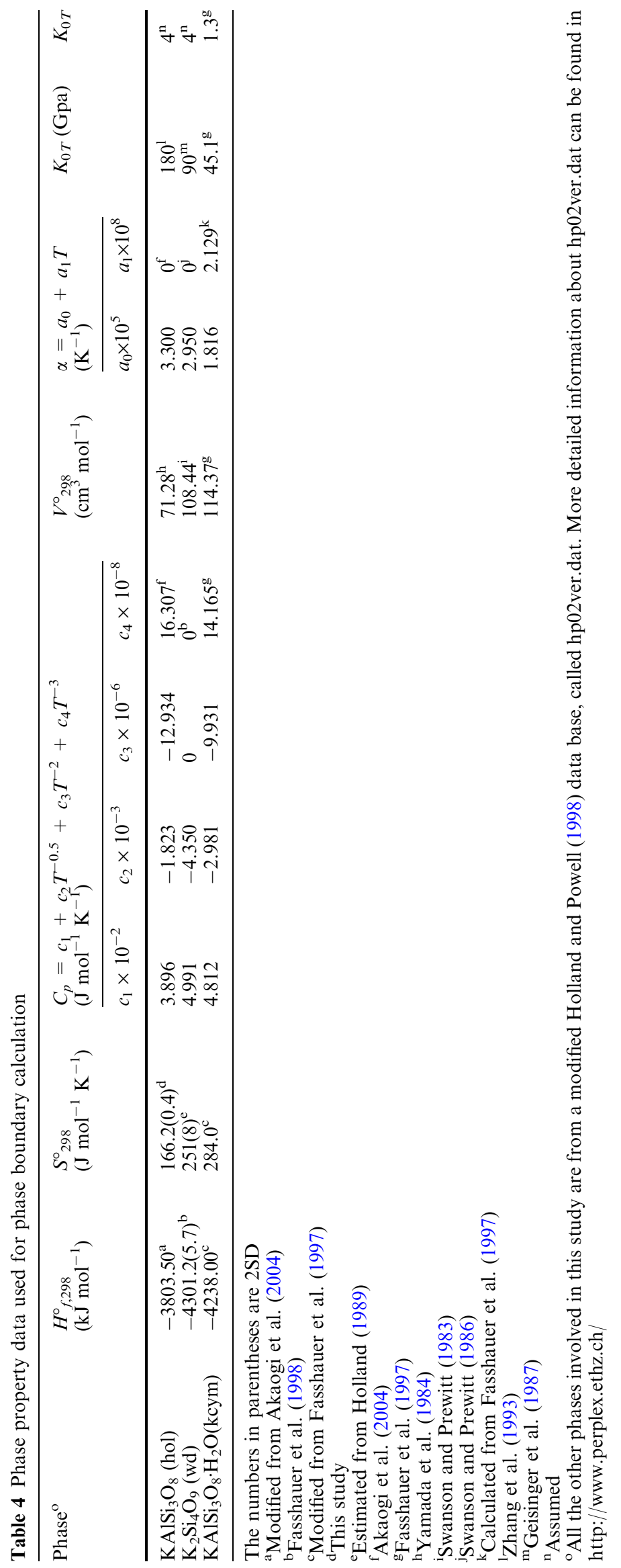


regression of a set of 60 experimentally measured entropies and volumes of silicates and oxides. $(S-$ $k V)_{\mathrm{SiO}_{2}}^{[4]}$ and $(S-k V)_{\mathrm{K}_{2}} \mathrm{O}(a)$ correspond the tetrahedral coordination for $\mathrm{SiO}_{2}$ and framework sites such as in feldspars for $\mathrm{K}_{2} \mathrm{O}$, respectively. However, the value of $(S-k V){ }_{\mathrm{SiO}_{2}}^{[6]}$, which represents the octahedral coordination for $\mathrm{SiO}_{2}$, is not included in that study. Here this value was calculated using stishovite data from Holland and Powell (1998) data base. The phase boundary of reaction (Eq. 4) calculated with the revised entropy of Si-wadeite fits the experimental data of Yagi et al. (1994) and Urakawa et al. (1994) reasonably well (the lower solid line in Fig. 2). A small modification from $\Delta H_{f, 298}^{\circ}=-3,801 \pm 8 \mathrm{~kJ} \mathrm{~mol}^{-1}$ to $\Delta H_{f, 298}^{\circ}=-3803.5 \mathrm{~kJ} \mathrm{~mol}^{-1}$ that is within the error of $\Delta H_{f, 298}^{\circ}$ of $\mathrm{KAlSi}_{3} \mathrm{O}_{8}$ hollandite was applied to bring the calculated phase boundaries of reaction (Eq. 5) and (6) into better agreement with the experimental data of Yagi et al. (1994) and Urakawa et al. (1994) (the upper solid line in Fig. 2). The calculated boundary for the decomposition of sanidine into kyanite, coesite, and Si-wadeite in Fig. 2 is almost identical to that determined by Akaogi et al. (2004), and reasonable consistency is obtained with the experimental results of Yagi et al. (1994) and Urakawa

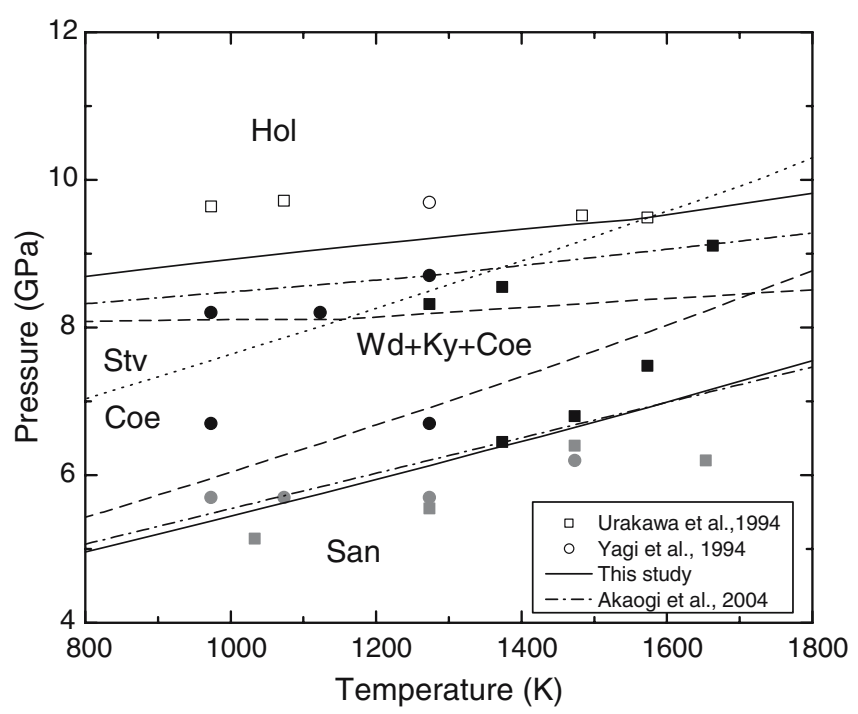

Fig. 2 Phase diagram of the system $\mathrm{KAlSi}_{3} \mathrm{O}_{8}$. The dotted line represents the coesite-stishovite transition boundary obtained with a modified Holland and Powell (1998) thermodynamic data base. Dashed lines show the phase boundaries calculated from $\left.S^{\circ}{ }_{298(W d}\right)=232 \mathrm{~J} \mathrm{~mol}^{-1} \mathrm{~K}^{-1}$ (Fasshauer et al. 1998). The solid line represents the phase boundaries calculated from $\left.S^{\circ}{ }_{298(\mathrm{Wd})}\right)=$ $251 \mathrm{~J} \mathrm{~mol}^{-1} \mathrm{~K}^{-1}$ and modified enthalpy of $\mathrm{KAlSi}_{3} \mathrm{O}_{8}$ hollandite. Dash-dotted lines are the phase boundaries of Akaogi et al. (2004). Circles represent quench experimental runs by Yagi et al. (1994) after pressure correction, and squares are the in situ X-ray experimental runs by Urakawa et al. (1994). Open, closed and shaded symbols represent hollandite, Si-wadeite + kyanite + coesite (or stishovite), and sanidine, respectively. $\mathrm{Hol} \mathrm{KAlSi}_{3} \mathrm{O}_{8}$ hollandite, $W d$ Si-wadeite, Ky kyanite, Coe coesite, Stv stishovite, San sanidine

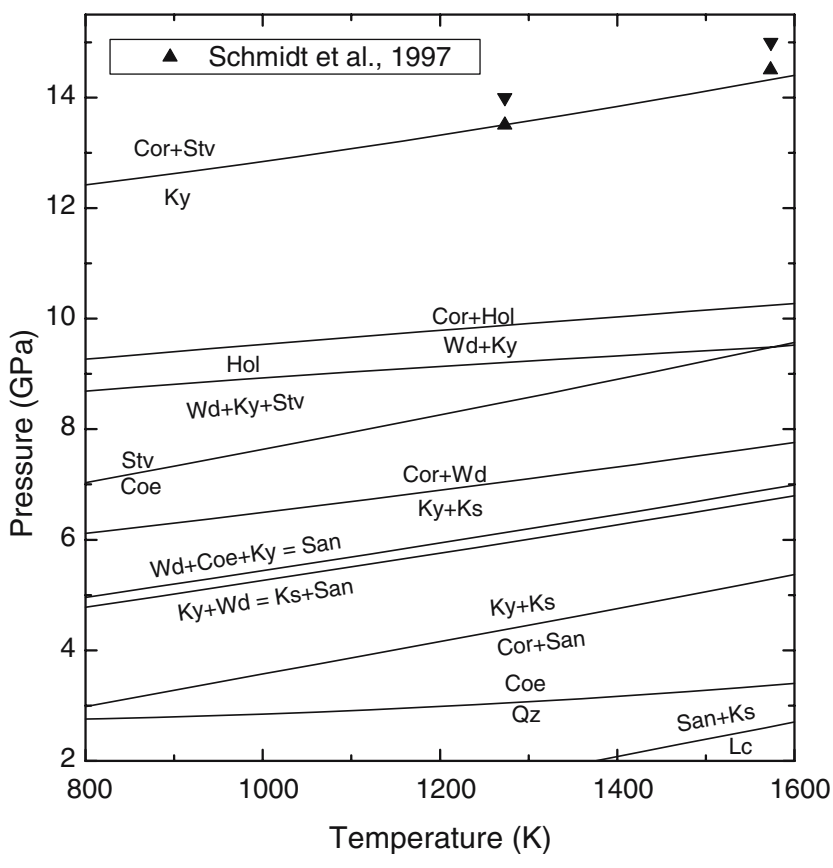

Fig. 3 Phase diagram of the system $\mathrm{K}_{2} \mathrm{O}-\mathrm{Al}_{2} \mathrm{O}_{3}-\mathrm{SiO}_{2}$. Triangles represent the experimental results of Schmidt et al. (1997). Cor corundum, $K s$ kalsilite, $Q z$ quartz, $L c$ leucite

et al. (1994) above 1,100 K. The difference between the experimental data and the calculated phase boundary below $1,100 \mathrm{~K}$ can be explained either by sluggish reaction rates or by remaining uncertainties in the thermodynamic properties (Akaogi et al. 2004). The phase boundary of Si-wadeite + kyanite $+\mathrm{SiO}_{2-}$ polymorph (stishovite or coesite) $=2 \mathrm{KAlSi}_{3} \mathrm{O}_{8}$ hollandite intersects the coesite-stishovite transition boundary at about $1,575 \mathrm{~K}$ and $9.5 \mathrm{GPa}$ (Fig. 2), which generates reaction (Eq. 5) at temperatures $>1,575 \mathrm{~K}$ and reaction (Eq. 6) at temperatures $<1,575 \mathrm{~K}$, respectively. The calculated locus of reactions (Eq. 5) and (6) is $0.3-0.4 \mathrm{GPa}$ higher than that of Akaogi et al. (2004). Choosing $8.7 \mathrm{GPa}$ at 1,273 K for the phase boundary from Akaogi et al. (2004) might be a source of the difference. Nonetheless, the result of this study and that of Akaogi et al. (2004) are consistent with the experimental study of Yagi et al. (1994) and Urakawa et al. (1994) within expected errors of a few kilobars.

Using the estimated values of entropy and the refined enthalpy data of $\mathrm{Si}$-wadeite and $\mathrm{KAlSi}_{3} \mathrm{O}_{8}$ hollandite as well as the modified Holland and Powell (1998) data base, a $P-T$ diagram for the system $\mathrm{K}_{2} \mathrm{O}-\mathrm{Al}_{2} \mathrm{O}_{3}-\mathrm{SiO}_{2}$ was calculated with Perple_x (Fig. 3). Fasshauer et al. (1998) suggested that sanidine would disproportionate first to kalsilite $\left(\mathrm{KAlSiO}_{4}\right)+$ coesite at around $5 \mathrm{GPa}$ when temperature is above $823 \mathrm{~K}$, and this assemblage would remain stable until pressure reaches 6-7 GPa. However, the calculated $P-T$ phase diagram in this study does not include a region where reaction (Eq. 4) is 
metastable. The reaction kalsilite + sanidine $=$ kyanite + Si-wadeite has been identified both by Fasshauer et al. (1998) and in this study, although the location of the boundary varies somewhat between the two works. For reactions with Si-wadeite, discrepancies between this study and Fasshauer et al. (1998) are mainly caused by different values of $S^{\circ}{ }_{298}$ for Si-wadeite. A calorimetric determination of $S^{\circ}{ }_{298}$ of Si-wadeite will be necessary to resolve remaining discrepancies in this system. Additional reactions involving corundum $\left(\mathrm{Al}_{2} \mathrm{O}_{3}\right)$, which Fasshauer et al. (1998) did not include in their study, have also been identified and located provisionally. The reaction kyanite $=$ corundum + stishovite is located at about $13-14 \mathrm{GPa}$ at $1,100-1,400 \mathrm{~K}$ and represents the upper stability of kyanite. The calculated phase boundary is $0.1-0.2 \mathrm{GPa}$ lower than the experimental results of Schmidt et al. (1997) (Fig. 3, triangles) at temperatures above $1,500 \mathrm{~K}$. The disagreement is certainly within expected experimental errors, especially those related to pressure calibration of multi-anvil apparatus. Errors in the calculation may derive from difficulties in extrapolating the $C_{p}$ data of stishovite to such high temperatures.

Phase equilibria in $\mathrm{K}_{2} \mathrm{O}-\mathrm{Al}_{2} \mathrm{O}_{3}-\mathrm{SiO}_{2}-\mathrm{H}_{2} \mathrm{O}$

At high pressures and in the presence of water, $\mathrm{K}$-feldspar reacts to form a hydrated phase $\mathrm{KAlSi}_{3} \mathrm{O}_{8} \cdot \mathrm{H}_{2} \mathrm{O}$, called "K-cymrite" (Massonne 1992) or "sanidine hydrate" (Thompson et al. 1998). A detailed crystal structure study of $\mathrm{KAlSi}_{3} \mathrm{O}_{8} \cdot \mathrm{H}_{2} \mathrm{O}$ by Fasshauer et al. (1997) suggests that it is indeed isostructural with $\mathrm{BaAl}_{2} \mathrm{Si}_{2} \mathrm{O}_{8} \cdot \mathrm{H}_{2} \mathrm{O}$ cymrite, although the $\mathrm{Al}$ and $\mathrm{Si}$ atoms

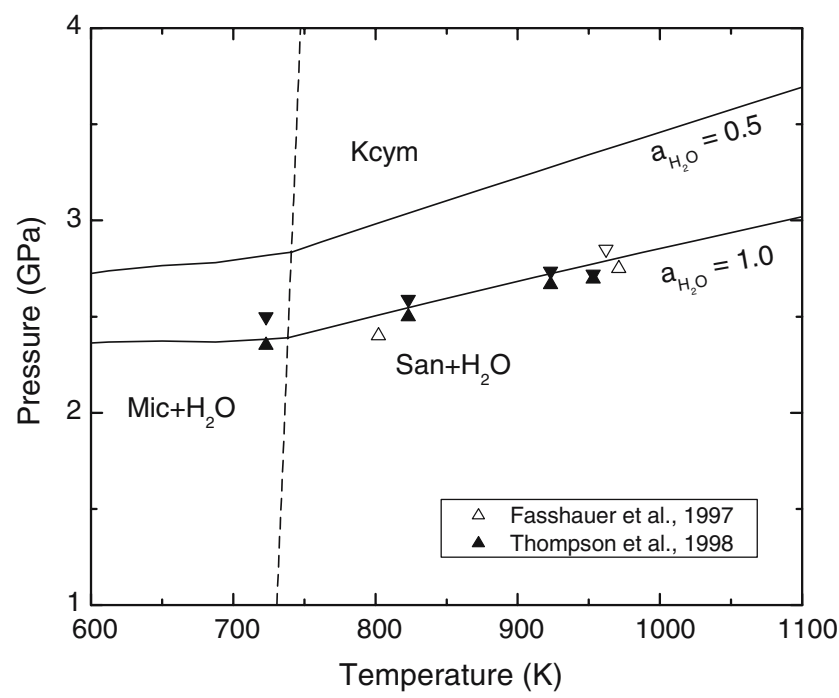

Fig. 4 Calculated $P-T$ diagram for the formation of K-cymrite. The open and closed triangles represent the experimental reversals by Fasshauer et al. (1997) and Thompson et al. (1998), respectively. The dashed line represents the microcline-sanidine transition boundary. Kcym K-cymrite, Mic microcline are highly disordered in $\mathrm{KAlSi}_{3} \mathrm{O}_{8} \cdot \mathrm{H}_{2} \mathrm{O}$ whereas in cymrite the $\mathrm{Al}$ and $\mathrm{Si}$ atoms are ordered. In this study the informal name K-cymrite will be used for the synthetic phase $\mathrm{KAlSi}_{3} \mathrm{O}_{8} \cdot \mathrm{H}_{2} \mathrm{O}$. Seki and Kennedy (1964) placed the phase boundary of the following reaction at around $1.8-2.8 \mathrm{GPa}$ and $700-1,000 \mathrm{~K}$ for $\mathrm{K}$-cymrite based on synthesis experiments of the following reaction:

sanidine $+\mathrm{H}_{2} \mathrm{O}=\mathrm{K}$-cymrite.

However, experiments by Massonne (1992) on this reaction yielded a much flatter slope at around $2.5 \mathrm{GPa}$, and this result was confirmed by reversed experiments of Fasshauer et al. (1997), Thompson (1994) and Thompson et al. (1998). Fasshauer et al. (1997) applied a Bayesian method to evaluate the thermodynamic properties of the phases in reaction (Eq. 9) and derived the standard enthalpy of formation and entropy for $\mathrm{K}$-cymrite. They treated the order-disorder relations of microcline to sanidine with a Landau formalism following Carpenter and Salje (1994). We recalculated the entropy and enthalpy of formation for K-cymrite to best fit the experimental reversals by Fasshauer et al. (1997) and Thompson et al. (1998). The revised thermodynamic data are shown in Table 4 and the best fit phase boundary is shown in Fig. 4. The revised enthalpy of formation and entropy for K-cymrite are $\sim 5 \mathrm{~kJ} \mathrm{~mol}^{-1}$ more negative and $\sim 8 \mathrm{~J} \mathrm{~mol}^{-1} \mathrm{~K}^{-1}$ more positive than the respective values of Fasshauer et al. (1997). They added a footnote that their enthalpy of $\mathrm{K}$-cymrite should be changed by $-7 \mathrm{~kJ} \mathrm{~mol}^{-1}$ to bring the enthalpy of microcline into accord with the data of Robie and Hemingway (1995). The enthalpy calculated in this study is in disagreement with the revised value of Fasshauer et al. (1997) by $+2 \mathrm{~kJ} \mathrm{~mol}^{-1}$, a relatively small error for such a calculation. The cause of the large discrepancy in the estimated entropy of $\mathrm{K}$-cymrite is unclear, because the compressibility and thermal expansion data of Fasshauer et al. (1997) for K-cymrite were used in the present calculations. The phase boundary for reaction (Eq. 9) calculated with the revised values of this study is in agreement with experimental reversals of Fasshauer et al. (1997) and Thompson et al. (1998). It is located at $<3 \mathrm{GPa}$ at $T<1,100 \mathrm{~K}$ (Fig. 4).

The pressure needed for the formation of K-cymrite is less than the peak pressure of many ultrahigh-pressure metamorphic (UHPM) rocks (e.g., Schertl et al. 1991; Sharp et al. 1993; Kaneko et al. 2000; Chopin 2003; Yoshida et al. 2004). In nature the $a_{\mathrm{H}_{2} \mathrm{O}}$ may be reduced from unity in the presence of other components such as $\mathrm{CO}_{2}$ or $\mathrm{NaCl}$, in the absence of a fluid phase, or in the presence of a melt (e.g., Edwards and Essene 1998; Valley et al. 1990). Reaction (Eq. 9) is successively shifted to higher pressures as $a_{\mathrm{H}_{2} \mathrm{O}}$ is reduced (Fig. 4), but even at an $a_{\mathrm{H}_{2} \mathrm{O}}$ of $0.5 \mathrm{~K}$-cymrite is still stable at UHPM conditions. It is expected that sanidine will hydrate to form K-cymrite during UHPM processes, although K-cymrite has not yet been reported in nature. 


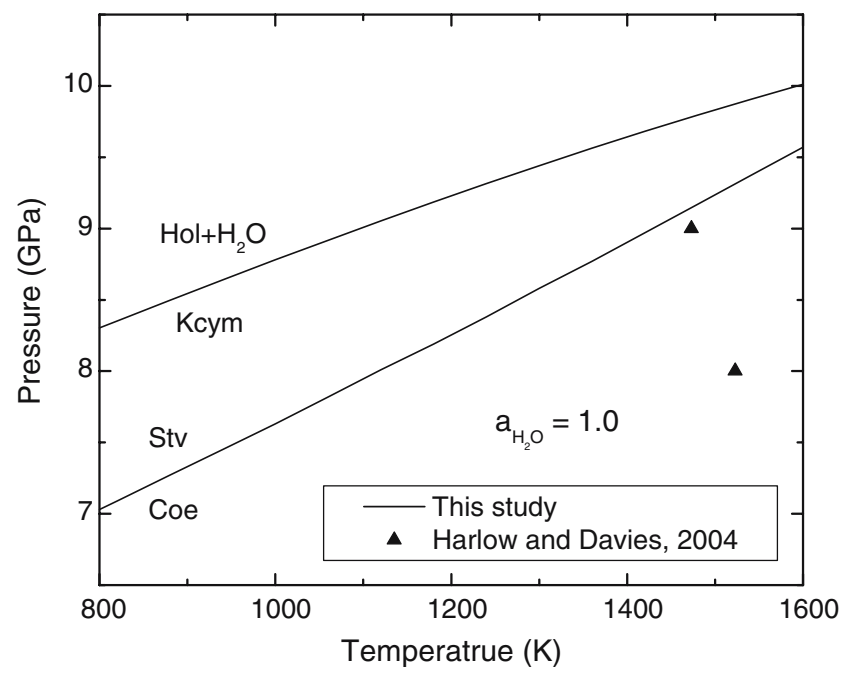

Fig. 5 Calculated $P-T$ diagram for the dehydration reaction of $\mathrm{K}$ cymrite into $\mathrm{KAlSi}_{3} \mathrm{O}_{8}$ hollandite. Closed triangles represent two experimental runs by Harlow and Davies (2004)

Hwang et al. (2004) discovered a new polymorph of $\mathrm{K}$-feldspar, kokchetavite, in the UHPM Kokchetav terrane of Kazahkstan. Reminiscent of the experiment by Thompson et al. (1998), who reported a hexagonal $\mathrm{KAlSi}_{3} \mathrm{O}_{8}$ phase (probably isostructural to kokchetavite) when K-cymrite is dehydrated at $T>1,273 \mathrm{~K}$ and ambient pressure, Hwang et al. (2004) suggested that kokchetavite could represent the dehydration product of K-cymrite during exhumation. Massonne and Nasdala (2003) also described inclusions in garnets made up of quartz, K-feldspar and micaceous material that possibly formed as pseudomorphs after $\mathrm{K}$-cymrite in a diamondiferous quartzofeldspathetic rock from the Erzgebirge, Germany. K-cymrite probably dehydrates rapidly to sanidine during exhumation of K-rich UHPM rocks, especially in those that attained relatively high metamorphic temperatures (973-1,173 K).

Harlow and Davies (2004) inferred a negative $P / T$ slope for the breakdown of K-cymrite based on two experimental runs: $9 \mathrm{GPa}$ at $1,473 \mathrm{~K}$ and $8 \mathrm{GPa}$ at $1,523 \mathrm{~K}$ for the reaction

$\mathrm{K}$-cymrite $=\mathrm{KAlSi}_{3} \mathrm{O}_{8}$ hollandite $+\mathrm{H}_{2} \mathrm{O}$.

However, the calculated phase transition boundary shows a slight positive $P / T$ slope, which lies $0.4-1.4 \mathrm{GPa}$ higher than the two experimental runs by Harlow and Davies (2004) (Fig. 5). A calorimetric study of K-cymrite and reversed experiments are indicated to address this discrepancy and better constrain the phase transition boundary of reaction (Eq. 10).

Faust and Knittle (1994) documented the breakdown of a natural muscovite, $\mathrm{KAl}_{3} \mathrm{Si}_{3} \mathrm{O}_{10}(\mathrm{OH})_{2}$, to $\mathrm{KAlSi}_{3} \mathrm{O}_{8}$ hollandite at pressures between 10.9 and $12 \mathrm{GPa}$ around $1,073 \mathrm{~K}$ via the following reaction:

muscovite $=\mathrm{KAlSi}_{3} \mathrm{O}_{8}$ hollandite + corundum $+\mathrm{H}_{2} \mathrm{O}$.

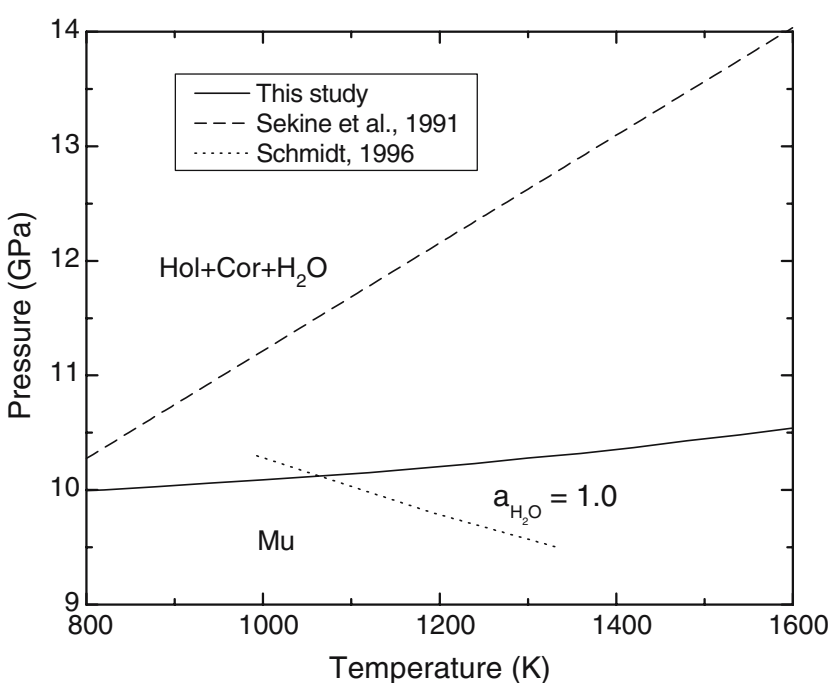

Fig. 6 Calculated $P-T$ diagram for the dehydration reaction of muscovite into $\mathrm{KAlSi}_{3} \mathrm{O}_{8}$ hollandite $+\mathrm{Al}_{2} \mathrm{O}_{3}+\mathrm{H}_{2} \mathrm{O}$. The solid line represents the calculated phase boundary in this study. The dashed line shows the calculated phase boundary by Sekine et al. (1991). The dotted line represents the breakdown reaction of phengite (a K-rich mica) by Schmidt (1996). Mu muscovite

The $P T$ location of reaction (Eq. 11) was calculated with Perple_x and the thermodynamic data in Table 4 (Fig. 6). This reaction is located at about $10.1 \mathrm{GPa}$ at $1,073 \mathrm{~K}$ and $10.5 \mathrm{GPa}$ at $1,600 \mathrm{~K}, \sim 1-2 \mathrm{GPa}$ lower than the experimental results by Faust and Knittle (1994). Considering the large pressure uncertainties in the laser-heated diamond cell experiments by Faust and Knittle (1994), the calculated phase boundary is considered to be in reasonable agreement with their experiments. The calculated reaction curve has a significantly different slope than that of Sekine et al. (1991) (dashed line in Fig. 6). The discrepancy may result from their placement of the then less well constrained reactions (Eq. 4) and (6), that were used to extrapolate the thermodynamic data of $\mathrm{KAlSi}_{3} \mathrm{O}_{8}$ hollandite. Experimental data on the breakdown reaction of phengite (a K-rich mica) to $\mathrm{KAlSi}_{3} \mathrm{O}_{8}$ hollandite by Schmidt (1996) are in good agreement with our calculations in this study and are plotted in Fig. 6 for comparison (dotted line).

Sekine et al. (1991) and Faust and Knittle (1994) reported two other decomposition reactions of muscovite:

muscovite $=$ K-cymrite + corundum.

2 muscovite $=$ Si-wadeite +2 kyanite + corundum

$$
+2 \mathrm{H}_{2} \mathrm{O} \text {. }
$$

These two reactions are thought to occur at low pressures. However, the present thermodynamic calculations show that reaction (Eq. 12) only proceeds above $1,700 \mathrm{~K}$, and reaction (Eq. 13) is metastable, as it is located at pressures $>\sim 11 \mathrm{GPa}$, where muscovite has already dehydrated to $\mathrm{KAlSi}_{3} \mathrm{O}_{8}$ hollandite + corundum $+\mathrm{H}_{2} \mathrm{O}$. 


\section{Discussion}

The calculated $P T$ locations of reactions (Eq. 5) and (6) constrain the lower stability limit of $\mathrm{KAlSi}_{3} \mathrm{O}_{8}$ hollandite at $9-10 \mathrm{GPa}$ for $T>1,000 \mathrm{~K}$. The occurrence of $\mathrm{KAlSi}_{3} \mathrm{O}_{8}$ hollandite with stishovite in melt veins of the shocked meteorite Zagami (Langenhorst and Poirier 2000) supports this calculation. Although Tutti et al. (2001) showed that $\mathrm{KAlSi}_{3} \mathrm{O}_{8}$ hollandite is stable up to $95 \mathrm{GPa}$, representing a depth of $2,200 \mathrm{~km}$ in the mantle, a study by Sueda et al. (2004) puts the upper $P$-stability limit of $\mathrm{KAlSi}_{3} \mathrm{O}_{8}$ hollandite at $22-24 \mathrm{GPa}$, where it transforms to a new phase, hollandite II. The locations of reaction (Eq. 10) and (Eq. 11) confirm that $\mathrm{KAlSi}_{3} \mathrm{O}_{8}$ hollandite is stable at pressures above $10 \mathrm{GPa}$. It appears $\mathrm{KAlSi}_{3} \mathrm{O}_{8}$ hollandite is stable down to depths of $400-660 \mathrm{~km}$ in the transition zone of the Earth's mantle, followed by hollandite II at greater depths.

Besides occurrences in shocked meteorites, $\mathrm{KAlSi}_{3} \mathrm{O}_{8}$ hollandite has also been reported as an experimental run product between 8 and $11 \mathrm{GPa}$ in bulk compositions corresponding to average continental crust, subducted terrigenous and pelagic sediment, basalts, and metapelites (Irifune et al. 1994; Domanik and Holloway 1996, 2000; Schmidt 1996; Ono 1998; Wang and Takahashi 1999). However, Si-wadeite has not yet been identified in any of these experiments or in natural occurrences. Wang and Takahashi (1999) argued that $\mathrm{K}$ might be selectively partitioned into pyroxene and/or garnet in potassic basalt, thus inhibiting the formation of Siwadeite in that bulk composition. In the presence of water, reaction (Eq. 9) will take place at much lower pressure than reaction (Eq. 4), which also prevents the formation of Si-wadeite from sanidine.

Acknowledgements The authors are grateful to C. Manning of UCLA for providing $2 \mathrm{~g}$ of sanidine glass for use in this study. They also thank Z. Page and C. Henderson for their help in EMPA analysis, and R.C. Rouse for his help with XRD measurements. The authors acknowledge M. Akaogi and J. Konzett for their constructive reviews of the manuscript. This work was partly supported by Scott Turner Research Grant by the Department of Geological Sciences, University of Michigan to the senior author, and by NSF grants EAR96-28196, 99-11352, 00-87448 and 05-37068 to EJE. NSF grants EAR 03-10142 and 00-79827 to M. Hirschmann for the multianvil device at the University of Minnesota, and support of the Austrian granting agency for the PPMS at the University of Salzburg (grant P15880-N11) are also gratefully acknowledged.

\section{References}

Akaogi M (2000) Clues from a shocked meteorite. Science 287:1602-1603

Akaogi M, Kamii N, Kishi A, Kojitani H (2004) Calorimetric study on high-pressure transitions in $\mathrm{KAlSi}_{3} \mathrm{O}_{8}$. Phys Chem Minerals 31:85-91

Carpenter MA, Salje EKH (1994) Thermodynamics of non-convergent cation ordering in minerals: III. Order parameter coupling in potassium feldspar. Am Mineral 79:1084-1098
Chopin C (2003) Ultrahigh-pressure metamorphism: tracing continental crust into the mantle. Earth Planet Sci Lett 212:1-14

Connolly JAD (1990) Multivariable phase diagrams: an algorithm based on generalized thermodynamics. Am J Sci 290:666-718

Connolly JAD, Kerrick DM (1987) An algorithm and computer program for calculating composition phase diagrams. CALPHAD 11:1-55

Dachs E, Bertoldi C (2005) Precision and accuracy of the heatpulse calorimetric technique: low temperature heat capacities of milligram-sized synthetic mineral samples. Eur J Mineral $17: 251-259$

Domanik KJ, Holloway JR (1996) The stability and composition of phengitic muscovite and associated phases from 5.5 to $11 \mathrm{GPa}$ : implications for deeply subducted sediments. Geochim Cosmochim Acta 60:4133-4150

Domanik KJ, Holloway JR (2000) Experimental synthesis and phase relations of phengitic muscovite from 6.5 to $11 \mathrm{GPa}$ in a calcareous metapelite from the Dabie Mountains, China. Lithos 52:51-77

Edwards RL, Essene EJ (1998) Pressure, temperature and C-O-H fluid fugacities across the amphibolite-granulite facies transition. NW, Adirondack Mtns., NY. J Petrol 29:39-73

Fasshauer DW, Chatterjee ND, Marler B (1997) Synthesis, structure, thermodynamic properties and stability relations of $\mathrm{K}$ cymrite, $\mathrm{KAlSi}_{3} \mathrm{O}_{8} \cdot \mathrm{H}_{2} \mathrm{O}$. Phys Chem Minerals 24:455-462

Fasshauer DW, Wunder B, Chatterjee ND, Höhne GWH (1998) Heat capacity of wadeite-type $\mathrm{K}_{2} \mathrm{Si}_{4} \mathrm{O}_{9}$ and the pressure-induced stable decomposition of K-feldspar. Contrib Mineral Petrol 131:210-218

Faust J, Knittle E (1994) The equation of state, amorphization, and high-pressure phase diagram of muscovite. J Geophys Res 99:19785-19792

Geisinger KL, Ross NL, McMillan P, Navrotsky A (1987) Potassium silicate $\left(\mathrm{K}_{2} \mathrm{Si}_{4} \mathrm{O}_{9}\right)$ : energetics and vibrational spectra of glass, sheet silicate, and wadeite-type phases. Am Mineral 72:984-994

Gillet P, Chen M, Dubrovinsky L, El Goresy A (2000) Natural $\mathrm{NaAlSi}{ }_{3} \mathrm{O}_{8}$-hollandite in the shocked Sixiangkou meteorite. Science 287:1633-1636

Harlow GE, Davies R (2004) Status report on stability of K-rich phases at upper-mantle conditions. Lithos 77:647-653

Holland TJB (1989) Dependence of entropy on volume for silicate and oxide minerals: a review and a predictive model. Am Mineral 74:5-13

Holland TJB, Powell R (1991) A compensated-Redlich-Kwong (CORK) equation for volumes and fugacities of $\mathrm{CO}_{2}$ and $\mathrm{H}_{2} \mathrm{O}$ in the range 1 bar to $50 \mathrm{kbar}$ and $100-1600^{\circ} \mathrm{C}$. Contrib Mineral Petrol 109:265-273

Holland TJB, Powell R (1998) An internally consistent thermodynamic data set for phases of petrological interest. J Metam Geol 16:309-343

Hwang SL, Shen P, Chu H-T, Yui T-F, Liou JG, Sobolev NV, Zhang R-Y, Shatsky VS, Zayachkovsky AA (2004) Kokchetavite: a new potassium-feldspar polymorph from the Kokchetav ultrahigh-pressure terrane. Contrib Mineral Petrol 148:380-389

Irifune T, Ringwood RE, Hibberson WO (1994) Subduction of continental crust and terrigenous and pelagic sediments: and experimental study. Earth Planet Sci Lett 126:351-368

Kaneko Y, Maruyama S, Terabayashi M, Yamamoto H, Ishikawa M, Anma R, Parkinson CD, Ota T, Nakajima Y, Katayama I, Yamamoto J, Yamauchi K (2000) Geology of the Kokchetav UHP-HP metamorphic belt, Northern Kazakhstan. Island Arc 9:264-283

Kimura M, Chen M, Yoshida Y, El Goresy A, Ohtani E (2003) Back-transformation of high-pressure phases in a shock melt vein of an $\mathrm{H}$-chondrite during atmospheric passage: implications for the survival of high-pressure phases after decompression. Earth Planet Sci Lett 217:141-150

Kinomura N, Kume N, Koizumi M (1975) Stability of $\mathrm{K}_{2} \mathrm{Si}_{4} \mathrm{O}_{9}$ with wadeite type structure. In: Proceedings of the 4th international conference on high pressure sci tech, pp 211-214 
Kinomura N, Koizumi M, Kume S (1977) Crystal structures of phases produced by disproportionation of K-feldspar under pressure. In: Manghnani MH, Akimoto S (eds) High-pressure research: application in geophysics. Academic, New York, pp 183-189

Konzett J, Fei Y (2000) Transport and storage of potassium in the earth's upper mantle and transition zone: an experimental study to $23 \mathrm{GPa}$ in simplified and natural bulk compositions. J Petrol 41:583-603

Langenhorst F, Poirier JP (2000) "Eclogitic" minerals in a shocked basaltic meteorite. Earth Planet Sci Lett 176:259-265

Lashley JC, Hundley MF, Migliori A, Sarrao JL, Pagliuso PG, Darling TW, Jaime M, Cooley JC, Hults WL, Morales L, Thoma DJ, Smith JL, Boerio-Goates J, Woodfield BF, Stewart GR, Fisher RA, Phillips NE (2003) Critical examination of heat capacity measurements made on a quantum design physical property measurement system. Cryogenics 43:369-378

Liu L (1978) High-pressure phase transitions of kalsilite and related potassium bearing aluminosilicates. Geochem J 12:275-277

Massonne H-J (1992) Evidence for low-temperature ultrapotassic siliceous fluids in subduction zone environments from experiments in the system $\mathrm{K}_{2} \mathrm{O}-\mathrm{MgO}-\mathrm{Al}_{2} \mathrm{O}_{3}-\mathrm{SiO}_{2}-\mathrm{H}_{2} \mathrm{O}$ (KMASH). Lithos 28:421-434

Massonne H-J, Nasdala L (2003) Characterization of an early metamorphic stage through inclusions in zircon of a diamondiferous quartzofeldspathic rock from the Erzgebirge, Germany. Am Mineral 88:883-889

Nishiyama N, Rapp RP, Irifune T, Sanehira T, Yamazaki D, Funakoshi K (2005) Stability and $P-V-T$ equation of state of $\mathrm{KAlSi}_{3} \mathrm{O}_{8}$-hollandite determined by in situ X-ray observations and implications for dynamics of subducted continental crust material. Phys Chem Mineral 32:627-637

Ono S (1998) Stability limits of hydrous minerals in sediment and mid-ocean ridge basalt compositions: implications for water transport in subduction zones. J Geophys Res 103:18253-18267

Prewitt CT, Downs RT (1998) High-pressure crystal chemistry. Rev Mineral 37:283-312

Ringwood AE (1975) Composition and petrology of the Earth's mantle. McGraw-Hill, New York, 618 pp

Ringwood AE, Reid AF, Wadsley AD (1967) High-pressure $\mathrm{KAlSi}_{3} \mathrm{O}_{8}$, an alumino-silicate with sixfold coordination. Acta Crystallogr 23:1093-1095

Robie RA, Hemingway BS (1995) Thermodynamic properties of minerals and related substances at $298.15 \mathrm{~K}$ and 1 bar $\left(10^{5}\right.$ Pascals) pressure and at higher temperatures. US Geological Survey 2131, $461 \mathrm{pp}$

Schertl H-P, Schreyer W, Chopin C (1991) The pyrope-coesite rocks and their country rocks at Parigi, Dora Maira massif, western Alps: detailed petrography, mineral chemistry and $P T$ path. Contrib Mineral Petrol 108:1-21

Schmidt M (1996) Experimental constraints on recycling of potassium from subducted oceanic crust. Science 272:19271930

Schmidt MW, Poly S, Comodi P, Zanazzi PF (1997) High-pressure behavior of kyanite: decomposition of kyanite into stishovite and corundum. Am Mineral 82:460-466
Seki Y, Kennedy GC (1964) The breakdown of potassium feldspar, $\mathrm{KAlSi}_{3} \mathrm{O}_{8}$, at high temperatures and high pressures. Am Mineral 49:1688-1706

Sekine T, Rubin AM, Ahrens TJ (1991) Shock wave equation of state of muscovite. J Geophys Res 96:19675-19680

Sharp ZD, Essene EJ, Hunziker JC (1993) Stable isotope geochemistry and phase equilibria of coesite-bearing whiteschists, Dora Maira massif, western Alps. Contrib Mineral Petrol 114:1-12

Sueda Y, Irifune T, Nishiyama N, Rapp RP, Ferroir T, Onozawa T, Yagi T, Merkel S, Miyajima N, Funakoshi K (2004) A new high-pressure form of $\mathrm{KAlSi}_{3} \mathrm{O}_{8}$ under lower mantle conditions. Geophys Res Lett 31:L23612. DOI 10.1029/2004GL021156

Swanson DK, Prewitt CT (1983) The crystal structure of $\mathrm{K}_{2} \mathrm{Si}^{\mathrm{VI}}$ $\mathrm{Si}_{3}^{\mathrm{IV}} \mathrm{O}_{9}$. Am Mineral 68:581-585

Swanson DK, Prewitt CT (1986) Anharmonic thermal motion in $\mathrm{K}_{2} \mathrm{Si}^{\mathrm{VI}}-\mathrm{Si}_{3}^{\mathrm{IV}} \mathrm{O}_{9}$. Eos 67:369

Thompson P (1994) The sanidine-'sanidine hydrate' reaction boundary. Mineral Mag 58A:897

Thompson P, Parsons I, Graham CM, Jackson B (1998) The breakdown of potassium feldspar at high water pressures. Contrib Mineral Petrol 130:176-186

Tomioka N, Mori H, Fujino K (2000) Shock-induced transition of $\mathrm{NaAlSi}_{3} \mathrm{O}_{8}$ feldspar into a hollandite structure in a L6 chondrite. Geophys Res Lett 278:3997-4000

Tutti F, Dubrovinsky LS, Saxena SK, Carlson S (2001) Stability of $\mathrm{KAlSi}_{3} \mathrm{O}_{8}$ hollandite-type structure in the Earth's lower mantle conditions. Geophys Res Lett 28:2735-2738

Urakawa S, Kondo T, Igawa N, Shimomura O, Ohno H (1994) Synchrotron radiation study on the high-pressure and hightemperature phase relations of $\mathrm{KAlSi}_{3} \mathrm{O}_{8}$. Phys Chem Mineral 21:387-391

Valley JW, Bohlen SR, Essene EJ, Lamb W (1990) Metamorphism in the Adirondacks. II. The role of fluids. J Petrol 31:555-596

Wang W, Takahashi E (1999) Subsolidus and melting experiments of a K-rich basaltic composition to $27 \mathrm{GPa}$ : implication for the behavior of potassium in the mantle. Am Mineral 84:357-361

Yagi A, Akimoto S (1976) Direct determination of coesite-stishovite transition by in situ X-ray measurements. Tectonophys 35:259-586

Yagi A, Suzuki T, Akaogi M (1994) High pressure transitions in the system $\mathrm{KAlSi}_{3} \mathrm{O}_{8}-\mathrm{NaAlSi}_{3} \mathrm{O}_{8}$. Phys Chem Minerals 21:1217

Yamada H, Matsui Y, Ito E (1984) Crystal-chemical characterization of $\mathrm{KAlSi}_{3} \mathrm{O}_{8}$ with hollandite structure. Mineral J 12:2934

Yoshida D, Hirajima T, Ishiwatari A (2004) Pressure-temperature path recorded in the Yangkou garnet peridotite, in $\mathrm{Su}-\mathrm{Lu}$ ultrahigh-pressure metamorphic belt, eastern China. J Petrol 45:1125-1145

Zhang J, Ko J, Hazen RM, Prewitt CT (1993) High-pressure crystal chemistry of $\mathrm{KAlSi}_{3} \mathrm{O}_{8}$ hollandite. Am Mineral 78:493499

Zhang J, Li B, Utsumi W, Liebermann RC (1996) In situ X-ray observations of the coesite-stishovite transition: reversed phase boundary and kinetics. Phys Chem Minerals 23:1-10 